\title{
Synthesis \\ Strengthening Environmental Foresight: Potential Contributions of Futures Research
}

David N. Bengston $^{1}$, George H. Kubik ${ }^{2,3}$, and Peter C. Bishop ${ }^{4}$

\begin{abstract}
The need for environmental foresight has increased in recent decades as the pace of change has accelerated and the frequency of surprise has increased. Successfully dealing with the growing impacts of change on social-ecological systems depends on our ability to anticipate change. But traditional scientific tools are blunt instruments for studying a future that does not exist. We propose that futures research, a transdisciplinary field of inquiry that has been developing for more than 50 years, offers an underused but fruitful set of approaches to address this important challenge. A few futures research methods-notably several forms of scenario analysis-have been applied to environmental issues and problems in recent years. But futurists have developed an array of other useful methods for exploring possible, plausible, and preferable futures, important insights into the nature of change, and perspectives for thinking creatively and deeply about the future. We present an overview of futures research and its potential to enrich environmental planning and policy by offering a cross-fertilization of new ideas and approaches, providing a more complete view of emerging environmental problems, and facilitating the development of strategies to increase adaptive capacity and deal more effectively with surprises.
\end{abstract}

Key Words: environmental futures, futures research, scenarios, strategic foresight

\section{INTRODUCTION}

The need for environmental foresight has increased in recent decades as the pace of change has accelerated and the frequency of surprise has increased. The Millennium Ecosystem Assessment concluded that "over the past 50 years, humans have changed ecosystems more rapidly and extensively than in any comparable period of time in human history, largely to meet rapidly growing demands for food, fresh water, timber, fiber, and fuel" (Millennium Ecosystem Assessment 2005:1). Surprises are increasing along with the expanding scale of human impacts (Gunderson and Folke 2008). Hibbard et al. (2007) refer to the period following World War II as the "Great Acceleration," a time of significant increase in the scope, scale, and intensity of impacts on the social-ecological system. Global indicators of the Great Acceleration discussed by Hibbard et al. (2007) include rapid growth in human populations, atmospheric carbon dioxide concentrations, average global temperatures, use of nitrogenous fertilizers, percent of marine fisheries fully exploited, and species extinctions. Add to these the rapid pace of technological change with the potential for sweeping environmental effects-such as genetic engineering and nanotechnologies-and it is clear that the need for environmental foresight has never been greater (Olson and Rejeski 2005).

In attempts to gain environmental foresight, substantial effort has been devoted to forecasting the future of social-ecological systems. But this work has been plagued by a host of shortcomings, and the track record has been poor at best (Sherden 1998, Sarewitz et al. 2000, Pilkey and Pilkey-Jarvis
2007). Ecological forecasts are filled with irreducible uncertainties due to drivers beyond the scope of ecology (for example, climate change, demographic change, management interventions), unknown feedbacks in coupled socialecological systems, and unpredictable human actions (Carpenter 2002). The complex interactions of people and ecosystems ensure that ecological forecasts are fundamentally uncertain. Experience in the social sciences confirms that predictions of most social phenomena are notoriously inaccurate. Sociologist Seymour Martin Lipset reviewed the accuracy of forecasts in economics, demography, sociology, and political science, and concluded that "Social scientists are good historians. They are able to understand the processes in what has already happened. But they have not been good forecasters" (Lipset 1983:157). Even the latest generation of economic forecasting models (dynamic stochastic general equilibrium models), the product of a decade of intense research, fails dismally at accurately forecasting basic economic variables, although the models perform no worse than other economic forecasting methods (Edge and Gurkaynak 2010).

The inability to successfully forecast the future of complex social-ecological systems stems from many factors, such as the emergent nature of these systems and their sensitive dependence on initial conditions. The phenomenon of emergence is ubiquitous in systems of various types (de Haan 2006). Emergent properties of a system cannot be predicted from the parts. Sensitivity to initial conditions implies that one may be able to predict the behavior of chaotic systems in the short term, but not in the medium or long term. Mathematician

${ }^{1}$ USDA Forest Service, Northern Research Station, ${ }^{2}$ Anticipatory Futures Group, LLC, ${ }^{3}$ University of Minnesota, Innovation Studies, ${ }^{4}$ Associate Professor of Strategic Foresight, Dept. of Futures Studies, The University of Houston 
and chaos theory pioneer Edward Norton Lorenz famously discovered that weather, a well-understood deterministic system, was a chaotic system that was unpredictable in the long range (Lorenz 1963). The prevalence of surprise in socialecological systems (Kates and Clark 1996, Gunderson and Longstaff 2010) implies that some important uncertainties in long-term forecasts are irreducible and that traditional scientific tools are blunt instruments for studying a future that does not exist.

The ineffectuality of predicting the future of social-ecological systems using traditional scientific methods, and the need to anticipate and prepare for change in a rapidly changing world pose a formidable challenge to environmental scientists and policy makers. We propose that futures research, a transdisciplinary field of inquiry that uses a variety of methods to explore alternative futures, offers an underused but fruitful set of approaches to this challenge. Futurists have developed an array of useful methods to explore alternative futures, important insights into the nature of change, and perspectives for thinking creatively and deeply about the future. Based on our experience, few environmental professionals are aware of futures research as a distinct transdisciplinary field of study -it is an invisible area to most, despite its long history of development and use in other sectors. We present an overview of futures research and its potential to enrich our understanding of the future context of social-ecological systems with a crossfertilization of new ideas and approaches. The next section presents a brief overview of futures research, followed by a description of several of the main methods developed and employed by futurists. Examples of several major efforts that use futures research in environmental contexts are described and key lessons learned are summarized. A concluding section outlines the potential benefits of utilizing the full range of futures methods and perspectives.

\section{AN OVERVIEW OF FUTURES RESEARCH}

Futures research, also called futures studies, futures, and strategic foresight, has been defined as "A methodologicalbased form of inquiry into alternative futures in terms of what is possible, probable, and/or preferable with the goal of anticipating and possibly influencing those futures" (Kubik 2009:x). Bell (1997) further characterizes futures research as a transdisciplinary social science and an "action science," with an orientation to informing decision making and action. Futures research is distinct from planning, although Cole (2001) notes a symbiosis between these two fields, and there is a clear but often overlooked link between futures research and strategic planning (Roney 2010). Both futures research and planning may identify preferable futures in terms of vision and goals. But where planning involves the development of a specific course of action to achieve stated goals, futures research focuses on the longer term and provides a much broader perspective and essential context to the specific concerns of planners.
A central principle of futures research is the importance of exploring and preparing for multiple plausible futures, not just the one considered most likely, because the future is fundamentally uncertain (Bishop et al. 2007). As futurist Herman Kahn (1982:82) stated, "The most likely future isn't." In other words, even what is considered to be the most likely future is a low probability event given the complex nature of social-ecological systems and the frequency of discontinuous change and surprise. The most disruptive type of discontinuous change is low probability but high impact events, often referred to as "wild cards" by futurists (Petersen 1997, Cornish 2004). Rather than attempt to predict the most likely future-which is typically the goal of traditional scientific forecasting - the goal of futures research is to explore a range of plausible alternative futures and preferable futures (Bishop 1998, Cornish 2004). The frequency of discontinuous change makes it vitally important that we think broadly about the future to minimize the risk of being surprised and unprepared.

The origins of futures research are sometimes traced back to a long tradition of utopian writings that explore preferred futures, beginning with the publication of Thomas More's Utopia in 1516. Bell (1997), Strathern (2007), and others have examined the early roots and many diverse strands of futures research that reveal the deep human need-rooted in survival - to anticipate and influence the future course of events. In the modern era, futures research is sometimes traced to the 1901 publication of H.G. Wells' Anticipations of the Reaction of Mechanical and Scientific Progress upon Human Life and Thought, which proposed a science of the future (Wager 1991). In 1932, Wells (1987) discussed the need for "professors of foresight" and university departments of foresight to anticipate and prepare for the future. But it was not until the post-World War II era that futures research began to take shape as a distinct field of study. Work on the future of military technology was carried out in the 1950s by RAND Corporation, a think tank that grew out of early operations research and systems analysis. RAND served as a school for many early futurists, including Herman Kahn, one of the pioneers of scenario analysis, and Olaf Helmer, who helped developed the Delphi method (discussed in the next section). The Defense Advanced Research Projects Agency-just one of many U.S. Department of Defense units that includes futures researchwas established in 1958 as a response to a wild card event: the Soviet Union's launching of Sputnik.

The development of futures research accelerated during the turbulent 1960s. Many futures organizations were founded at this time, including the USA-based World Future Society in 1966 and the internationalist World Futures Studies Federation in 1967. Best-selling futures books such as Future Shock (Toffler 1970), Limits to Growth (Meadows et al. 1972), and Megatrends (Naisbitt 1982) captured the public's imagination and elevated popular awareness of futures 
research. Numerous futures research journals have appeared, including Foresight, Futures, Futures Research Quarterly, Futuribles (in French), Futurics, Journal of Futures Studies, On the Horizon, The Futurist, Technological Forecasting and Social Change, and World Future Review. Many business journals, such as International Journal of Forecasting, Long Range Planning, and Strategic Management Journal, regularly publish futures research along with traditional forecasting and planning literature. Academic futures programs have also developed around the world, and the World Futures Studies Federation (2012) has compiled a list of the various tertiary futures educational programs. The World Future Society's annual conference currently attracts about 1,000 attendees, and their Futurist Directory lists nearly 1,400 people professionally involved in the study of the future (World Future Society 2000). A major global futures research effort, the Millennium Project (http://www.millennium-project. org), was initiated in 1992 by the Smithsonian Institution, The Futures Group International, and the United Nations University. The Millennium Project is now an independent, nonprofit futures research think tank with 35 nodes around the world, and produces an annual "State of the Future" report as well as many special studies.

Within futures research, a variety of distinct traditions has developed since the 1960s. Futurists hold many different views of what futures research is and how the study of the future should be approached (Inayatullah 1996). Gidley et al. (2009) identify five traditions, which they label as predictiveempirical, critical-postmodern, cultural-interpretive, prospectiveaction (or participatory futures), and integrative-holistic. Detailing these traditions or other proposed typologies of futures research is beyond the scope of this paper, but each can generate useful insights depending on the decision context. Multiple traditions are often employed in futures research as a strategy for dealing with uncertainty.

In sum, futures research is now a mature transdisciplinary field of study with a considerable body of literature, many specialized journals, professional organizations, and distinct methods for studying possible, plausible, and preferable futures (some of which are outlined in the following section). But the majority of futures research remains invisible to the scholarly community and the public because it takes place in military units, intelligence agencies, and corporations around the world, and is hence proprietary or confidential. In nearly all major corporations, applied futures research is quietly carried out either by a dedicated futures group or, more often, under rubrics such as strategic planning, long-range planning, technological forecasting, strategy development, and horizon scanning. Limited versions of this research are sometimes published (e.g., CIA 2000, Royal Dutch/Shell Group 2005, Chief of Force Development 2010), but most is closely guarded and confidential. Thus, due to the proprietary nature of most futures research, the published literature is the tip of a much larger iceberg (Bell 1997).

\section{SELECTED FUTURES RESEARCH METHODS}

As a transdisciplinary field of inquiry, futures research embraces methodological pluralism, the philosophy of science that claims multiple disciplinary approaches, frameworks of analysis, and ways of knowing are required to understand complex systems or phenomena (Norgaard 1989). Consequently, futurists have developed a wide range of methods and borrowed or adapted methods from many fields. A comprehensive futures project usually involves multiple methods to address different dimensions of the problem. Several leading futurists have provided exhaustive reviews of futures research methods (e.g., Fowles 1978, Helmer 1983, Glenn and Gordon 2009). We review several of the main methods used in futures research-including scanning, visioning, the Delphi method, and scenarios—and give a short example of each.

\section{Scanning}

Scanning, also called horizon scanning, environmental scanning, or critical trends analysis, refers to a wide range of processes for identifying and understanding significant emerging trends in the external environment of an organization (e.g., a government agency, corporation, or nongovernmental organization) or an area of interest (e.g., biological diversity, climate change, or ecosystem services). Ideally, scanning serves as an early warning system to identify potential threats and opportunities. The goal is to find nascent indications of future developments that may be important. Gordon and Glenn (2009:4) characterize scanning as "the central input to futures research," because scanning broadly for emerging trends is often a component of other methods used in futures research, such as scenario analysis. Techniques for systematically gathering and analyzing trends expressed in current literature were originally developed by military intelligence officers to gain insights into emerging developments in enemy countries (Cornish 2004). Scanning was used extensively during World War II and has long been standard practice in business as well as many government agencies. The digital age has transformed scanning, and there are now hundreds of approaches tailored to specific decision-making contexts, all of which involve identifying and classifying trends or potential trends into categories. A widely used trends classification system, developed by marketing professor Philip Kotler, includes six broad categories with the acronym DEGEST: Demography, Economy, Government, Environment, Society/culture, and Technology (Kotler and Keller 2008).

Scanning systems typically involve several components. First is the ongoing search of a wide range of information sources, such as database literature reviews, expert panels, and specific websites and publications. Relevant information is entered 
into a searchable database. To avoid information overload by management, items entered into the database are analyzed, synthesized, and made accessible to managers in a variety of ways. A key element of effective scanning systems is feedback from management to the scanning team so the system can "learn" to produce the most germane information and improve performance (Gordon and Glenn 2009).

Futurists generally take a broader approach to scanning than is commonly used in the business world (Slaughter 1999) because they have found that changes in seemingly unrelated external areas can have unexpected and profound effects. Schwartz (1991:60) describes strategies and tactics for "hunting and gathering of information," and recommends seeking out potential trends on the fringe of society rather than in the mainstream, and from unorthodox sources and thinkers. Annual series that identify emerging trends, such as the Millennium Project's State of the Future (Glenn et al. 2011) and the World Future Society's Outlook series (Futurist Editorial Staff 2010) are examples of scanning output and can serve as input into other scanning work or futures projects.

Although scanning is a widely used and well understood futures method, the application of formal scanning approaches to environmental contexts and organizations is quite limited. However, there have been several instances in which the importance of this approach has been recognized. For example, the National Advisory Council for Environmental Policy and Technology recommended that the U.S. Environmental Protection Agency (EPA) create an ongoing, institutionalized scanning system (U.S. EPA 2002). Sutherland and Woodroof (2009) describe the usefulness of scanning applied to environmental issues and present a taxonomy of scanning methods, and Sutherland et al. (2008, 2010) outline the results of scanning exercises related to biodiversity and global conservation issues. The U.S. Army has an Environmental Policy Institute that conducts futures scanning on environmental issues (http://www.aepi.army.mil/ ) .

\section{Visioning}

Visioning, or preferred futures, methods involve identifying and choosing a preferred image of the future, a vital step in most comprehensive futures research projects (Hines and Bishop 2007). A vision is a compelling statement of the future that a group or organization wants to create based on shared deep values and purpose (Bezold 2009), or an idealized state that conveys the possibility of future attainment (Huber 1978). According to Lippitt (1998), shared visions of the future should entail several components: clarity, shared understanding, specific imagery, strategic orientation, and group buy-in. Images of the future are important because they enhance options and possibilities in the present (Slaughter 1995). Costanza (2000:1) expressed the importance of a positive vision of our environmental future: "The most critical task facing humanity today is the creation of a shared vision of a sustainable and desirable society."

"Future workshops" to create visions of preferred futures were organized and conducted in Europe by writer and futurist Robert Jungk beginning in 1962 (Jungk and Mullert 1987). The three-day workshops began with a day of thoroughly critiquing the situation being addressed, followed by a day of brainstorming about possible solutions. The most promising ideas were then selected democratically and small groups developed them into feasible projects. The workshops concluded with an implementation phase in which constraints and obstacles were examined and a plan of action was developed. While Jungk and others were conducting future workshops in Europe, Americans Edward Lindaman and Ronald Lippitt created a similar method called Preferred Futuring. Various forms of Preferred Futuring have been used by tens of thousands of organizations in recent decades (Lippitt 1998).

Bookman (2000) describes one of the few comprehensive examples of visioning applied to an environmental concern: an effort to develop a vision of the future of coastal areas in the U.S. and a subsequent national dialogue to disseminate the vision. The National Ocean Service of the National Oceanic and Atmospheric Administration coordinated development of the vision among 10 diverse national organizations involved with coastal areas during the 1998 International Year of the Ocean. The process included a conference on coastal trends and a forum on coastal stewardship. The final vision for "Coastal Futures 2025" addressed 11 major themes ranging from community heritage to water-borne commerce (Bookman 2000). An interactive, six-month long Internetbased "Town Meeting on America's Coastal Future" was then conducted to disseminate and promote discussion of the vision. Analysis of results of the town meeting showed widespread support for most of the 11 themes and their specific goals and objectives, as well as areas of dissent, and many ideas for implementing the vision.

\section{The Delphi Method}

Named after the ancient Greek oracle, the Delphi method is a futures research technique that solicits and structures the opinions of a panel of experts over multiple rounds to develop assessments of alternative futures (Kubik 2009). This method was developed at the RAND Corporation in the early 1950s in a study of the likely effects of nuclear war (Linstone and Turoff 1975). Early applications of this method were dominated by forecasting advancements in science and technology, following the lead of the classic Delphi study by Gordon and Helmer (1964). The Delphi method, in its various forms, has been applied in thousands of studies internationally in many fields and for a wide range of purposes (Gordon 2007). 
In a typical Delphi process, panel experts respond independently and anonymously to questions about possible future developments during the first round without knowledge of the responses of other panel members. During subsequent rounds, each participant is presented with the range of results from the entire panel in the previous round along with their own response from that round. Participants are asked to consider the results, paying particular attention to the basis for responses that lie at either end of the distribution. They then have the opportunity to revise their individual responses based on the responses and rationales of other participants. Delphi studies typically involve 2-5 rounds, at which time a group consensus or contrasting views of the future developments may emerge. Critcher and Gladstone (1998) have cautioned that attempting to force a consensus in Delphi-based studies may invalidate the results. One of the creators of the Delphi method claimed that consensus is not the preferred outcome (Helmer 1983). Rather, the stability of responses is the objective, a state in which none of the participants would change their view based on more discussion, even though they may disagree. Exploring contrasting views and minority opinions may be essential for understanding irreducible uncertainty. In addition to the identification of uncertainty and divergence, important contributions of Delphi studies are the ideas generated (e.g., the desirability of some future state, or the means of achieving or avoiding a future state), and arguments for extreme positions of participants (Gordon 2009).

The Delphi method has occasionally been applied to natural resource and environmental issues. One of the earliest applications was a 1974 study titled "Future leisure environments" (Shafer et al. 1974). In this wide-ranging and ambitious study, the researchers developed forecasts for 125 possible future events in five broad topic areas: natural resource management, wildland recreation management, pollution, population-workforce-leisure, and urban environments. Other environmental applications of Delphi include Leitch and Leistritz (1984) and Plummer and Armitage (2007).

\section{Scenarios}

Scenario development and analysis is the most widely used futures research tool for helping decision makers and all stakeholders think creatively about a range of plausible futures in a world of great uncertainty. Glenn and The Futures Group International (2009:2) define a scenario as “... a story with plausible cause and effect links that connects a future condition with the present, while illustrating key decisions, events, and consequences throughout the narrative." Bishop et al. (2007) have called scenarios the heart and archetypical product of futures research. The scenario method was developed by Herman Kahn and others at RAND Corporation and was first brought to public attention by Kahn's influential books (e.g., Kahn 1962, Kahn and Weiner 1967). Scenario analysis has been widely used for many decades in military and business planning (Bradfield et al. 2005). More than two dozen specific techniques for developing scenarios have been identified, and Bishop et al. (2007) discuss eight broad types of scenario development methods. The output of scenario analysis is a set of stories or narratives. The stories are not predictions but represent a range of plausible futures intended to help decision makers and others build adaptive capacity to make their systems more resilient to change by preparing for a diverse set of alternatives.

Unlike other futures research methods, scenarios have increasingly been applied to environmental issues in recent years. There are growing numbers of large-scale environmental studies that include or are based on scenario methods. Examples include the Intergovernmental Panel on Climate Change (IPCC) reports (IPCC 2007), the Millennium Ecosystem Assessment (Carpenter et al. 2005, Raskin 2005), and the World Water Vision Exercise (Cosgrove and Rijsberman 2000). Alcamo (2008) provides a wide-ranging examination of the practice of scenario analysis applied to environmental issues and problems, including guidelines for conducting scenario studies, methodological issues, shortcomings of current practice, and dealing with surprise.

In addition to applications of expert-based scenario analysis to global environmental issues and assessments, participatory scenarios have been used in several local or regional contexts. For example, Evans et al. (2010) describe the application and evaluation of participatory scenario analysis in forest communities in Bolivia and Vietnam. This study was part of an effort by the Center for International Forestry Research to help local forest stakeholders plan for the future and improve the participation of forest communities in decisions that affect them (Wollenberg et al. 2000, Evans et al. 2006). Other examples of participatory scenario analysis applied to environmental issues include an Australian case study that focused on social resilience in climate-vulnerable communities (Gidley et al. 2009), and an assessment of future ecosystem services in northern Wisconsin, USA (Peterson et al. 2003).

Many other futures research methods have been developed by futurists or adapted from other fields, each with unique advantages and disadvantages depending on the context. For example, the Millennium Project's "Futures Research Methodology — v.3.0" (Glenn and Gordon 2009) details more than 30 individual methods, including the futures wheel, crossimpact analysis, technology sequence analysis, and relevance trees. New methods continue to be developed, such as causal layered analysis (Inayatullah 2004) and methods involving the use of online social networks (Cachia et al. 2007). Taken together, these methods constitute a powerful tool kit for exploring and reflecting on the fundamental uncertainties about future developments in complex adaptive systems. 


\section{EXAMPLES OF MAJOR ENVIRONMENTAL FUTURES PROJECTS}

We briefly describe three large-scale applications of environmental futures research and key lessons that have been learned. All except the first example are applications of scenario analysis, which is indicative of the dominance of this method in environmental contexts.

The longest running effort to apply futures research to environmental issues is the work carried out by the U.S. EPA, dating back to the early 1970s (U.S. EPA 1973, Elgin et al. 1975). Environmental foresight activities have been carried out on a small scale by various offices and divisions within the EPA, including an Environmental Futures Committee established in the 1990s. Some of this work was carried out in partnership with the Institute for Alternative Futures (http: //www.altfutures.com). The motivation for the EPA's futures research has been the belief that it is essential for the EPA and other environmental agencies “... to anticipate future environmental problems, and then take steps to avoid them, not just respond to them after the fact" (U.S. EPA 1995:1). Early futures projects at the EPA helped give legitimacy to futures research within the agency but were "one shot" efforts rather than part of a systematic and ongoing environmental futures program. In 1999, an agency-wide "futures network" was created to stimulate futures thinking throughout the organization and promote capacity for environmental foresight (Olson and Street 2002). Futures research continues to take place within the agency (e.g., U.S. EPA 2002, 2007), but on a modest scale.

A recent review of the EPA's futures research activities (Olson 2011) concluded that these efforts are fragile and could easily be lost because they have not been institutionalized in a way that will assure continuity. Olson identified several lessons that have emerged from the EPA's experience, including the importance of (1) linking futures research to senior career executives and having a high-level champion who will support this work over time; (2) developing ties to other parts of the organization to avoid becoming isolated; (3) having a dedicated staff and budget line item to support futures research; (4) framing efforts around stimulating and informing strategic conversations and making better decisions today rather than "knowing the future"; and (5) making an ongoing horizon scanning system a core activity.

Another area where substantial environmental futures research has been carried out is the voluminous literature that applies scenario analysis to the issue of climate change. Climate change is a natural fit for futures research because of the long time horizons and multiple uncertainties. Most climate change scenario analysis has used a quantitative modeling approach, and most has been carried out under the auspices of the IPCC (e.g., Nakicenovic et al. 2000, Morita et al. 2001, Carter et al. 2007), dating back to the IPCC emission scenarios of the early 1990s (Leggett et al. 1992). Over the past 20 years, the sophistication of the IPCC scenario work has increased markedly. Recent IPCC scenario analyses include the blending of quantitative modeling and narrative approaches, incorporating stakeholder participation, and adopting multisectoral, multi-stressor, and multi-scale approaches to climate change scenarios (Carter et al. 2007).

The IPCC scenarios have produced many insights for climate change policy. For example, Parson et al. (2007) identified the following most significant policy lessons: (1) scenarios that produce similar emissions in the long-term future may follow distinctly different paths over time, thereby resulting in sizeable differences in cumulative emissions; (2) technology and energy-resource assumptions can generate as wide a range of future emissions as large variations in economic and demographic assumptions; and (3) significantly different combinations of socioeconomic and energy market conditions can result in comparable emissions trajectories, indicating that specific trajectories with different driving factors can result in distinct mitigation problems for policy makers. The IPCC scenarios have also generated a variety of criticisms and controversies, and new approaches for creating climate change scenarios are being pursued to address some of these issues (Moss et al. 2010).

The Millennium Ecosystem Assessment (MA) included another application of scenario analysis to a global environmental issue. The MA was a large-scale, 4-year process that focused on the conditions of ecosystems, change in the provision of ecosystem services, implications for human well-being, and options for policy responses (Carpenter et al. 2006). The Scenarios Working Group of the MA interviewed 59 diverse leaders from around the world about their environmental and social concerns for the next 50 years (Bennett et al. 2005). The interview results suggested there were four broad clusters of beliefs about the future. These were developed into four scenarios, all of which began at current conditions and then branched off into alternative futures depending on key assumptions. The MA scenarios technical volume presents a detailed description of the development and use of the scenarios (Carpenter et al. 2005).

A number of insights emerged from the MA scenarios, including the close association between poverty reduction and provision of ecosystem services, the difficult trade-offs between different ecosystem services, and trade-offs between present and future supply of a given service. Overall, the scenarios were deemed to provide rich and valuable perspectives on plausible futures at the global and broad regional levels, but the models were not able to examine local processes and impacts related to ecosystem services (Nakicenovic et al. 2005). The development of regional and sub-regional scenarios in future assessments has been proposed as a means to both examine more place-specific 
issues and to help inform and improve global scenarios. In addition, better communication and interaction with policy makers and across scientific disciplines have been identified as important ways to increase the relevance of the MA scenarios to decision makers (Nakicenovic et al. 2005).

\section{CONCLUSIONS AND FUTURE LESSONS TO BE LEARNED}

We have provided a brief overview of futures research as an essential but, to date, limited contributor to environmental science and policy. Futures research explores a range of possible, plausible, and preferable futures, and examines their implications for planning, management, and policy. The methods of futures research have been developed and productively applied in many domains over the past 50 years, yet they have been applied infrequently to environmental issues with the exception of the recent increase in the use of scenario analysis. These recent applications of a core futures research method are encouraging and have demonstrated its usefulness and potential contributions. The need to consider alternative futures for sound policy and planning in a world of rapid and unexpected change suggests that futures research could make a much greater contribution.

There are several potential benefits of fully integrating futures research and thinking - and the full array of futures methods and approaches-into environmental endeavors. These can be thought of as future lessons to be learned from the application of futures research. First, the more relevant perspectives we can bring to bear on a problem, the more holistic and complete our solution will be (Floyd and Zubevich 2010). If efforts to address complex environmental problems routinely overlooked important economic or cultural aspects, the chances of successfully dealing with them would be slim. Similarly, if futures research is a vital but often neglected dimension in the environmental arena, as we have argued, then the likelihood of successfully addressing long-term environmental issues may be substantially reduced without the development and application of strategic foresight resulting from futures research.

Second, futures research encourages decision makers to think big. With its transdisciplinarity, methodological pluralism, and insights into the nature of change, futures research can help all stakeholders take a broader and more creative view. Futures research promotes thinking big in terms of multiple disciplinary perspectives, creative problem solving, and a systems perspective, in addition to the obvious inclusion of temporal scales that are beyond the range usually considered in environmental decision making. The complexity of environmental problems requires envisioning a wide and creative range of alternative futures, and resilient decisions must include consideration of the broad context.

Third, futures research can help identify and highlight potential unintended consequences of new technologies, social trends, and proposed policies. Anticipating unintended consequences is a critical need as the pace of change has increased and risks have become more complex. Several futures methods are designed to explore unintended consequences. For example, the futures wheel is a strategic thinking technique for visualization of first-order and higher order consequences of a trend or development (Glenn 2009). Cross-impact analysis is a method for exploring how relationships between possible events (and other variables) could impact one another. Originally developed by futurists in the 1960s, various approaches to cross-impact analysis have been used extensively in the business and intelligence communities as well as by futures think tanks (Heuer and Pherson 2011). A better understanding of potential unintended consequences can help in the design of policies and strategies that will minimize negative consequences and enhance resilience.

Fourth, solving complex environmental problems requires taking into account a diversity of perspectives. Complex problems may be solved more effectively with a diverse team than by the best individual experts (Page 2007). Carpenter et al. (2009:1) argued that “ $\ldots$ the consideration of a wide range of perspectives is a hallmark of resilient decision making in the face of unexpected change." Participatory futures methods offer effective ways to incorporate the varied views of diverse individuals. For example, a recent evaluation of the usefulness of participatory scenario methods identified a large number of benefits, and some important pitfalls, and concluded that the methods ".... are effective participatory tools for helping forest dependent communities prepare for the future, identify opportunities and threats, and make decisions" (Evans et al. 2010:616). In addition to participatory scenario planning, other futures techniques-such as public Delphi, Future Search Conferences, and preferred futuring methods-have long been used to incorporate a diversity of viewpoints.

Fifth, the frequency of surprise in social-ecological systems suggests another benefit. Environmental futures research can help explore key uncertainties and identify potential surprises -most importantly surprises from other domains that will have environmental effects-thereby facilitating the development of policies to increase adaptive capacity to deal with surprises (Bennett et al. 2003). Futurists have developed strategies to identify and prepare for wild cards and "black swan" events (e.g., Petersen 1997, Toth 2008, Petersen and Steinmueller 2009, Taleb 2010). Futures thinking can train us to expect the unexpected, thereby helping to build greater resilience of systems to surprise.

Finally, insights about a range of possible and plausible futures of social-ecological systems can help decrease reaction time as events rapidly unfold. A classic business example is Royal Dutch Shell's response to the 1973-74 OPEC oil embargo and price shock. Unlike the other global oil companies, Royal 
Dutch Shell's executives responded quickly because they had been alerted to the possibility of this event through scenario planning and had explored possible responses in advance (Schwartz 1991). They had rehearsed the future and were therefore able to respond swiftly. Given the prevalence of rapid and surprising change, even unlikely events should be prepared for to ensure a quick response if the consequences are great enough.

The long-term nature of and inherent uncertainties surrounding environmental problems have encouraged attempts to "look beyond the headlights," but these efforts have often been limited in scope. Futures research offers a way to strengthen this vital dimension of the study of socialecological systems. The practicality of this perspective is indicated by the fact that corporate, military, and intelligence strategists have played a dominant role in developing and applying futures research methods. As Schwartz (1991:221) observed, “... people at resilient companies continually hold strategic conversations about the future." Resilient socialecological systems also call for ongoing conversations about the future and the tools and perspectives of futures research.

Responses to this article can be read online at: http://www.ecologyandsociety.org/vol17/iss2/art10/ responses/

\section{Acknowledgments:}

The authors thank Roger Caldwell, Bernie Lewis, Emily Peters, Susan Stewart, Lynne Westphal, and two anonymous reviewers for many insightful suggestions and comments on earlier drafts of this paper.

\section{LITERATURE CITED}

Alcamo, J., editor. 2008. Environmental futures: the practice of environmental scenario analysis. Elsevier, Amsterdam, The Netherlands.

Bell, W. 1997. Foundations of futures studies, volume 1: history, purposes, and knowledge. Transaction Publishers, New Brunswick, New Jersey, USA.

Bennett, E. M., S. R. Carpenter, G. D. Peterson, G. S. Cumming, M. Zurek, and P. Pingali. 2003. Why global scenarios need ecology. Frontiers in Ecology and the Environment 1(6):322-329. http://dx.doi.org/10.1890/1540-9295 (2003)001[0322:WGSNE]2.0.CO;2

Bennett, E. M., G. D. Peterson, and E. A. Levitt. 2005. Looking to the future of ecosystem services. Ecosystems 8:125-132. http://dx.doi.org/10.1007/s10021-004-0078-y

Bezold, C. 2009. Using vision in futures planning. In J. C. Glenn and T. J. Gordon, editors. Futures research methodology—version 3.0 (CD-ROM). The Millennium Project, Washington, D.C., USA.

Bishop, P. 1998. Thinking like a futurist. The Futurist 32 (5):39-42.

Bishop, P, A. Hines, and T. Collins. 2007. The current state of scenario development: an overview of techniques. Foresight 9(1):5-25. http://dx.doi.org/10.1108/14636680710 $\underline{727516}$

Bookman, C. S. 2000. Town meeting on America's coastal future: using the Internet to promote coastal stewardship. Ocean \& Coastal Management 43:937-951. http://dx.doi.org /10.1016/S0964-5691(00)00065-X

Bradfield, R., G. Wright, G. Burt, G. Cairns, and K. Van Der Heijden. 2005. The origins and evolution of scenario techniques in long range business planning. Futures 37 (8):795-812. http://dx.doi.org/10.1016/j.futures.2005.01.003

Cachia, R., R. Compañó, and O. Da Costa. 2007. Grasping the potential of online social networks for foresight. Technological Forecasting \& Social Change 74(8):11791203. http://dx.doi.org/10.1016/j.techfore.2007.05.006

Carter, T. R., R. N. Jones, X. Lu, S. Bhadwal, C. Conde, L. O. Mearns, B. C. O'Neill, M. D. A. Rounsevell, and M. B. Zurek. 2007. New assessment methods and the characterisation of future conditions. Pages 133-171 in M. L. Parry, O. F. Canziani, J. P. Palutikof, P. J. van der Linden, and C. E. Hanson, editors. Climate change 2007: impacts, adaptation and vulnerability. Contribution of Working Group II to the Fourth Assessment Report of the Intergovernmental Panel on Climate Change. Cambridge University Press, Cambridge, UK.

Carpenter, S. R. 2002. Ecological futures: building an ecology of the long now. Ecology 83(8):2069-2083. http://dx.doi.org/ $\underline{10.2307 / 3072038}$

Carpenter, S. R., E. M. Bennett, and G. D. Peterson. 2006. Scenarios for ecosystem services: an overview. Ecology and Society 11(1):29. [online] URL: http://ecologyandsociety.org/ vol11/iss $1 /$ art29/

Carpenter, S. R., C. Folke, M. Scheffer, and F. R. Westley. 2009. Resilience: accounting for the noncomputable. Ecology and Society 14(1):13. [online] URL: http://www.ecologyand society.org/vol14/iss1/art13/

Carpenter, S. R., P. L. Pingali, E. M. Bennett, and M. B. Zurek, editors. 2005. Ecosystems and human well-being: volume 2 scenarios - findings of the Scenarios Working Group (Millennium Ecosystem Assessment Series). Island Press, Washington, D.C., USA. 
Central Intelligence Agency (CIA). 2000. Global trends 2015: a dialogue about the future with nongovernmental experts. [online] URL: http://www.dni.gov/nic/PDF GIF global/glob altrend2015.pdf

Chief of Force Development. 2010. The future of the security environment, 2008-2030. Part 1: current and emerging trends. Chief of Force Development, National Defense Headquarters, Ottawa, Ontario, Canada. [online] URL: http:// www.cfd-cdf.forces.gc.ca/sites/page-eng.asp?page $=7241$

Cole, S. 2001. Dare to dream: bringing futures into planning. Journal of the American Planning Association 67(4):372-383. http://dx.doi.org/10.1080/01944360108976246

Cornish, E. 2004. Futuring: the exploration of the future. World Future Society, Bethesda, Maryland, USA.

Cosgrove, W. J., and F. R. Rijsberman. 2000. World water vision: making water everybody's business. World Water Council. Earthscan, London, UK.

Costanza, R. 2000. Visions of alternative (unpredictable) futures and their use in policy analysis. Conservation Ecology 4(1):5. [online] URL: http://www.consecol.org/vol4/iss1/art5

Critcher, C., and B. Gladstone. 1998. Utilizing the Delphi technique in policy discussion: a case study of a privatized utility in Britain. Public Administration 76:431-449. http://dx doi.org/10.1111/1467-9299.00110

de Haan, J. 2006. How emergence arises. Ecological Complexity 3(4):293-301. http://dx.doi.org/10.1016/j.ecocom .2007 .02 .003

Edge, R., and R. S. Gurkaynak. 2010. How useful are estimated DSGE model forecasts for central bankers? Brookings Papers on Economic Activity (BPEA), Fall 2010. Brookings Institution, Washington, D.C., USA. [online] URL: http://ww w.brookings.edu/ /media/Files/Programs/ES/

BPEA/2010 fall bpea papers/2010fall edgegurkaynak.pdf

Elgin, D. S., D. C. MacMichael, and P. Schwartz. 1975. Alternative futures for environmental policy planning: 19752000. EPA-540/9-75-027. Prepared by Stanford Research Institute Center for the Study of Social Policy for EPA Office of Pesticide Programs, Strategic Studies Unit. Washington, D. C., USA.

Evans, K., W. De Jong, P. Cronkleton, and T. H. Nghi. 2010. Participatory methods for planning the future in forest communities. Society and Natural Resources 23:604-619. http://dx.doi.org/10.1080/08941920802713572

Evans, K., S. J. Velarde, R. P. Prieto, S. N. Rao, S. Sertzen, K. Davila, P. Cronkleton, and W. de Jong. 2006. Field guide to the future: four ways for communities to think ahead. Center for International Forestry Research, Alternative to Slash and Burn Consortium, World Agroforestry Centre, Nairobi, Kenya.

Floyd, J., and K. Zubevich. 2010. Linking foresight and sustainability: an integral approach. Futures 42(1):59-68. htt p://dx.doi.org/10.1016/j.futures.2009.08.001

Fowles, J., editor. 1978. Handbook of futures research. Greenwood Press, Westport, Connecticut, USA.

Futurist Editorial Staff. 2010. Outlook 2011 (supplement). The Futurist 44(6): 10 pages.

Gidley, J. M., J. Fien, J. A. Smith, D. C. Thomsen, and T. F. Smith. 2009. Participatory futures methods: towards adaptability and resilience in climate-vulnerable communities. Environmental Policy and Governance 19(6):427-440. http:/ /dx.doi.org/10.1002/eet.524

Glenn, J. C. 2009. Futures wheel. In J. C. Glenn and T. J. Gordon, editors. Futures research methodology-version 3.0 (CD-ROM). The Millennium Project, Washington, D.C., USA.

Glenn, J. C., and The Futures Group International. 2009. Scenarios. In J. C. Glenn and T. J. Gordon, editors. Futures research methodology-version 3.0 (CD-ROM). The Millennium Project, Washington, D.C., USA.

Glenn, J. C., and T. J. Gordon, editors. 2009. Futures research methodology-version 3.0 (CD-ROM). The Millennium Project, Washington, D.C., USA. [online] URL: http://www. millennium-project.org/millennium/FRM-V3.html\#toc

Glenn, J. C., T. J. Gordon, and E. Florescu, editors. 2011. 2011 state of the future (CD-ROM). The Millennium Project, Washington, D.C., USA.

Gordon, T. J. 2007. Energy forecasts using a "roundless" approach to running a Delphi study. Foresight 9(2):27-35. http://dx.doi.org/10.1108/14636680710737731

Gordon, T. J. 2009. The Delphi method. In J. C. Glenn, and T. J. Gordon, editors. Futures research methodology—version 3.0 (CD-ROM). The Millennium Project, Washington, D.C., USA.

Gordon, T. J., and J. C. Glenn. 2009. Environmental scanning. In J. C. Glenn, and T. J. Gordon editors. Futures research methodology—version 3.0 (CD-ROM). The Millennium Project, Washington, D.C., USA.

Gordon, T. J., and O. Helmer. 1964. Report on a long-range forecasting study. RAND Paper P-2982. RAND Corporation, Santa Monica, California, USA.

Gunderson, L., and C. Folke. 2008. A different future. Ecology and Society 13(2):57. [online] URL: http://www.ecologyands ociety.org/vol13/iss2/art57/ 
Gunderson, L., and P. Longstaff, editors. 2010. Managing surprises in complex systems: multidisciplinary perspectives on resilience. (Special feature). Ecology and Society 14(1):49. [online] URL: http://www.ecologyandsociety.org/vol14/iss1/ $\underline{\operatorname{art} 49 /}$

Helmer, O. 1983. Looking forward: a guide to futures research. Sage Publications, Beverly Hills, California, USA.

Heuer, R. J., and R. H. Pherson. 2011. Structured analytic techniques for intelligence analysis. CQ Press, Washington, D.C., USA.

Hibbard, K. A., P. J. Crutzen, E. F. Lambin, D. M. Liverman, N. J. Mantua, J. R. McNeil, B. Messerli, and W. Steffen. 2007. Group report: decadal-scale interactions of humans and the environment. Pages 341-375 in R. Costanza, L. J. Graumlich, and W. Steffen, editors. Sustainability or collapse? An integrated history and future of people on earth. MIT Press, Cambridge, Massachusetts, USA.

Hines, A., and P. Bishop, editors. 2007. Thinking about the future: guidelines for strategic foresight. Social Technologies, Washington, D.C., USA.

Huber, B. J. 1978. Images of the future. Pages 179-224 in J. Fowles, editor. Handbook of futures research. Greenwood Press, Westport, Connecticut, USA.

Inayatullah, S. 1996. What futurists think: stories, methods and visions of the future. Futures 28(6/7):509-517. http://dx. doi.org/10.1016/0016-3287(96)84430-2

Inayatullah, S., editor. 2004. The causal layered analysis (CLA) reader: theory and case studies of an integrative and transformative methodology. Tamkang University Press, Graduate Institute of Futures Studies, Tamsui, Taipei, Taiwan.

Intergovernmental Panel on Climate Change (IPCC). 2007. Summary for policymakers. In S. Solomon, D. Qin, M. Manning, Z. Chen, M. Marquis, K. B. Averyt, M. Tignor, and H. L. Miller, editors. Climate change 2007: the physical science basis. Contribution of Working Group I to the Fourth Assessment Report of the Intergovernmental Panel on Climate Change. Cambridge University Press, Cambridge, UK. [online] URL: http://www.ipcc.ch/pdf/assessment-report/ar4/ wg1/ar4-wg1-spm.pdf

Jungk, R., and N. Mullert. 1987. Future workshops: how to create desirable futures. Institute for Social Inventions, London, UK.

Kahn, H. 1962. Thinking about the unthinkable. Horizon Press, New York, New York, USA.

Kahn, H. 1982. The coming boom: economic, political and social. Simon and Schuster, New York, New York, USA.
Kahn, H., and A. J. Weiner. 1967. The year 2000: a framework for speculation on the next thirty-three years. MacMillan, New York, New York, USA.

Kates, R. W., and W. C. Clark. 1996. Environmental surprise: expecting the unexpected. Environment 38(2):6-11, 28-34. http://dx.doi.org/10.1080/00139157.1996.9933458

Kotler, P., and K. L. Keller. 2008. Marketing management. Thirteenth edition. Prentice Hall, Upper Saddle River, New Jersey, USA.

Kubik, G. H. 2009. Projected futures in competency development and applications: a Delphi study of the future of the wildlife biology profession. Dissertation. University of Minnesota, Minneapolis, Minnesota, USA.

Leggett, J., W. J. Pepper, and R. J. Swart. 1992. Emission scenarios for the IPCC: an update. In IPCC, climate change 1992: the supplementary report to the IPCC Scientific Assessment. Cambridge University Press, Cambridge, UK.

Leitch, J. A., and F. L. Leistritz. 1984. Delphi analysis: a technique for identifying and ranking environmental and natural resource policy issues. Environmental Professional 6 (1):32-40.

Linstone, H. A., and M. Turoff. 1975. Introduction. Pages 312 in H. A. Linstone, and M. Turoff, editors. The Delphi method: techniques and applications. Addison Wesley Publishing, Reading, Massachusetts, USA.

Lippitt, L. L. 1998. Preferred futuring: envision the future you want and unleash the energy to get there. Berrett-Koehler Publishers, San Francisco, California, USA.

Lipset, S. M. 1983. On the limits of social science. Pages 149168 in R. B. Smith, editor. An introduction to social research: volume I of handbook of social science methods. Ballinger, Cambridge, Massachusetts, USA.

Lorenz, E. N. 1963. Deterministic nonperiodic flow. Journal of the Atmospheric Sciences 20:130-141. http://dx.doi.org/10 $.1175 / 1520-0469(1963) 020<0130: \mathrm{DNF}>2.0 . \mathrm{CO} ; 2$

Meadows, D. H., D. L. Meadows, J. Randers, and W. W. Behrens III. 1972. Limits to growth: a report for The Club of Rome's project on the predicament of mankind. Universe Books, New York, New York, USA.

Millennium Ecosystem Assessment. 2005. Ecosystems and human well-being: synthesis. Island Press, Washington, D.C., USA.

Morita, T., J. Robinson, A. Adegbulugbe, J. Alcamo, D. Herbert, E. L. La Rovere, N. Nakicenovic, H. Pitcher, P. Raskin, K. Riahi, A. Sankovski, V. Sokolov, B. de Vries, and D. Zhou. 2001. Greenhouse gas emission mitigation scenarios and implications. Pages 115-166 in IPCC. Climate change 
2001: mitigation. Contribution of Working Group III to the Third Assessment Report of the Intergovernmental Panel on Climate Change. Cambridge University Press, Cambridge, UK.

Moss, R. H., J. A. Edmonds, K. A. Hibbard, M. R. Manning, S. K. Rose, D. P. van Vuuren, T. R. Carter, S. Emori, M. Kainuma, T. Kram, G. A. Meehl, J. F. B. Mitchell, N. Nakicenovic, K. Riahi, S. J. Smith, R. J. Stouffer, A. M. Thomson, J. P. Weyant, and T. J. Wilbanks. 2010. The next generation of scenarios for climate change research and assessment. Nature 463:747-756. http://dx.doi.org/10.1038/n $\underline{\text { ature } 08823}$

Naisbitt, J. 1982. Megatrends: ten new directions transforming our lives. Warner Books, New York, New York, USA.

Nakicenovic, N., J. Alcamo, G. Davis, B. de Vries, J. Fenhann, S. Gaffin, K. Gregory, A. Grubler, T. Y. Jung, T. Kram, E. L. La Rovere, L. Michaelis, S. Mori, T. Morita, W. Papper, H. Pitcher, L. Price, K. Riahi, A. Roehrl, H-H. Rogner, A. Sankovski, M. Schlesinger, P. Shukla, S. Smith, R. Swart, S. van Rooijen, N. Victor, and Z. Dadi. 2000. Special report on emissions scenarios (SRES). A special report of Working Group III of the Intergovernmental Panel on Climate Change. Cambridge University Press, Cambridge, UK.

Nakicenovic, N., J. McGlade, S. Ma, J. Alcamo, E. Bennett, W. Cramer, J. Robinson, F. L. Toth, and M. Zurek. 2005. Lessons learned for scenario analysis. Pages 449-467 in Ecosystems and human well-being. Volume 2: scenarios. Island Press, Washington, DC, USA.

Norgaard, R. B. 1989. The case for methodological pluralism. Ecological Economics 1(1):37-57. http://dx.doi.org/10.1016/ 0921-8009(89)90023-2

Olson, B. 2011. Environmental futures research at the U.S. Environmental Protection Agency. International Symposium on Society and Resource Management. June 4-8, 2011, Madison, Wisconsin, USA.

Olson, B., and A. Street. 2002. Foresight: the U.S. Environmental Protection Agency. Scenario and Strategy Planning (March-April):14-19.

Olson, R., and D. Rejeski, editors. 2005. Environmentalism and the technologies of tomorrow: shaping the next industrial revolution. Island Press, Washington, D.C., USA.

Page, S. E. 2007. The difference: how the power of diversity creates better groups, firms, schools, and societies. Princeton University Press, Princeton, New Jersey, USA.

Parson, E., V. Burkett, K. Fisher-Vanden, D. Keith, L. Mearns, H. Pitcher, C. Rosenzweig, and M. Webster. 2007. Global change scenarios: their development and use. Sub-report 2.1B of Synthesis and Assessment Product 2.1 by the U.S. Climate
Change Science Program and the Subcommittee on Global Change Research. Department of Energy, Office of Biological \& Environmental Research, Washington, D.C., USA.

Petersen, J. L. 1997. Out of the blue: wild cards and other big future surprises: how to anticipate and respond to profound change. Arlington Institute, Arlington, Virginia, USA.

Petersen, J., and K. Steinmueller. 2009. Wild cards. Chapter 10 in J. C. Glenn and T. J. Gordon editors. Futures research methodology-version 3.0. (CD-ROM). The Millennium Project, Washington, D.C., USA.

Peterson, G. D., T. C. Beard, Jr., B. E. Beisner, E. M. Bennett, S. R. Carpenter, G. S. Cumming, C. L. Dent, and T. D. Havlicek. 2003. Assessing future ecosystem services: a case study of the Northern Highland Lake District, Wisconsin. Ecology and Society 7(3):1. [online] URL: http://www.ecolog yandsociety.org/vol7/iss3/art1

Pilkey, O. H., and L. Pilkey-Jarvis. 2007. Useless arithmetic: why environmental scientists can't predict the future. Columbia University Press, New York, New York, USA.

Plummer, R., and D. R. Armitage. 2007. Charting the new territory of adaptive co-management: a Delphi study. Ecology and Society 12(2):10. [online] URL: http://www.ecologyands ociety.org/vol12/iss2/art10/

Raskin, P. D. 2005. Global scenarios: background review for the Millennium Ecosystem Assessment. Ecosystems 8 (2):133-142. http://dx.doi.org/10.1007/s10021-004-0074-2

Roney, C. W. 2010. Intersections of strategic planning and futures studies: methodological complementarities. Journal of Futures Studies 15(2):71-100.

Royal Dutch/Shell Group. 2005. Shell global scenarios to 2025. Shell International Limited, London, UK.

Sarewitz, D., R. A. Pielke, Jr., and R. Byerly, Jr., editors. 2000. Prediction: science, decision making, and the future of nature. Island Press, Washington, D.C., USA.

Schwartz, P. 1991. The art of the long view: planning for the future in an uncertain world. Currency Doubleday, New York, New York, USA.

Shafer, E. L., G. H. Moeller, and R. E. Getty. 1974. Future leisure environments. U.S. Forest Service, Research Paper NE-301, Northeastern Forest Experiment Station, Upper Darby, Pennsylvania, USA. http://www.fs.fed.us/ne/newtown square/publications/research papers/pdfs/scanned/OCR/ne rp301. pdf

Sherden, W. A. 1998. The fortune sellers: the big business of buying and selling predictions. John Wiley, New York, New York, USA. 
Slaughter, R. A. 1995. The foresight principle: cultural recovery in the $21^{\text {st }}$ century. Praeger, Westport, Connecticut, USA.

Slaughter, R. A. 1999. A new framework for environmental scanning. Foresight 1(5):441-451. http://dx.doi.org/10.1108/ $\underline{14636689910802331}$

Strathern, O. 2007. A brief history of the future. Robinson, London, UK.

Sutherland, W. J., M. J. Bailey, I. P. Bainbridge, T. Brereton, J. T. Dick, J. Drewitt, N. K. Dulvy, N. R. Dusic, R. P. Freckleton, K. J. Gaston, P. M. Gilder, R. E. Green, L. Heathwaite, S. M. Johnson, D. W. Macdonald, R. Mitchell, D. Osborn, R. P. Owen, J. Pretty, S. V. Prior, H. Prosser, A. S. Pullin, P. Rose, A. Stott, T. Tew, C. D. Thomas, D. B. A. Thompson, J. A. Vickery, M. Walker, C. Walmsley, S. Warrington, A. R. Watkinson, R. J. Williams, R. Woodroffe, and H. J. Woodroof. 2008. Future novel threats and opportunities facing UK biodiversity identified by horizon scanning. Journal of Applied Ecology 45(3):821-833. http://d x.doi.org/10.1016/j.tree.2009.04.008

Sutherland, W. J., M. Clout, I. M., Côté, P. Daszak, M. H. Depledge, L. Fellman, E. Fleishman, R. Garthwaite, D. W. Gibbons, J. De Lurio, A. J. Impey, F. Lickorish, D. Lindenmayer, J. Madgwick, C. Margerison, T. Maynard, L. S. Peck, J. Pretty, S. V. Prior, K. H. Redford, J. P. W. Scharlemann, M. Spalding, and A. R. Watkinson. 2010. A horizon scan of global conservation issues for 2010. Trends in Ecology and Evolution 25(1):1-7. http://dx.doi.org/10.1016/ j.tree.2009.10.003

Sutherland, W. J., and H. J. Woodroof. 2009. The need for environmental horizon scanning. Trends in Ecology and Evolution 24(10):523-527. http://dx.doi.org/10.1016/j.

tree.2009.04.008

Taleb, N. N. 2010. The black swan: the impact of the highly improbable. Second edition. Random House, New York, New York, USA.

Toffler, A. 1970. Future shock. Random House, New York, New York, USA.

Toth, F. L. 2008. Chapter Eight: Dealing with surprises in environmental scenarios. Pages 169-193 in J. Alcamo, editor. Environmental futures: the practice of environmental scenario analysis. Elsevier, Amsterdam, The Netherlands. http://dx.doi. org/10.1016/S1574-101X(08)00408-0

United States Environmental Protection Agency (U.S. EPA). 1973. Working papers in alternative futures and environmental quality. August 1973 (revised November 1973). U.S. Environmental Protection Agency, Office of Research and Development, Washington Environmental Research Center, Environmental Studies Division, Washington, D.C., USA.
United States Environmental Protection Agency (U.S. EPA). 1995. Beyond the horizon: using foresight to protect the environmental future. EPA-SAB-EC-95-007. U.S. Environmental Protection Agency, Science Advisory Board, Environmental Futures Committee, Washington, D.C., USA.

United States Environmental Protection Agency (U.S. EPA). 2002. The environmental future: emerging challenges and opportunities for EPA. EPA 100-R-02-001. Report from the National Advisory Council for Environmental Policy and Technology (NACEPT), Washington, D.C., USA.

United States Environmental Protection Agency (U.S. EPA). 2007. Shaping our environmental future: foresight in the Office of Research and Development. U.S. Environmental Protection Agency, Office of Science Policy, Office of Research and Development, Washington, D.C., USA.

Wager, W. W. 1991. The next three futures. Praeger, New York, New York, USA.

Wells, J. G. 1987 (1932). Wanted-professors of foresight! Futures Research Quarterly 3(1):89-91.

Wollenberg, E., D. Edmunds, and L. Buck. 2000. Using scenarios to make decisions about the future: anticipatory learning for the adaptive co-management of community forests. Landscape and Urban Planning 47(1-2):65-77. [online] URL: http://dx.doi.org/10.1016/S0169-2046(99)00071-7

World Future Society. 2000. The futurist directory: a guide to individuals who write, speak, or consult about the future. World Future Society, Bethesda, Maryland, USA.

World Futures Studies Federation. 2012. Tertiary Futures Education. [online] URL: http://wfsf.org/index.php?option=c om $\_$content\&view $=$section\&id $=16 \&$ Itemid $=108$ 